GOMES, GP; ZEFFA, DM; FREIRIA, GH; FURLAN, FF; QUEIROZ, RA; TAKAHASHI, LSA; GONÇALVES, LSA. 2020. Diallel analysis of “dedo-demoça" pepper seeds in relation to physiological potential. Horticultura Brasileira 38: 301-305. http://dx.doi.org/10.1590/S0102-053620200310

\title{
Diallel analysis of "dedo-de-moça" pepper seeds in relation to physiological potential
}

\author{
Gisely Paula Gomes ${ }^{1 \mathbb{D}}$; Douglas $M$ Zeffa ${ }^{2 \mathbb{D}}$; Gustavo Henrique Freiria ${ }^{3 \mathbb{D}}$; Felipe F Furlan ${ }^{4} \mathbb{D}$; Robison \\ Alesandro de Queiroz ${ }^{5 \mathbb{D}}$; Lúcia SA Takahashi ${ }^{1 \mathbb{D}}$; Leandro SA Gonçalves ${ }^{1 \mathbb{D}}$
}

${ }^{1}$ Universidade Estadual de Londrina (UEL), Londrina-PR, Brasil; gipgomes@yahoo.com.br; sadayo@uel.br; leandrosag@uel.br; ${ }^{2}$ Universidade Estadual de Maringá (UEM), Maringá-PR, Brasil; douglas.mz@hotmail.com; 3nniversidade do Estado de Minas Gerais (UEMG), Ituiutaba-MG, Brasil; gustavo.freiria@uemg.br; ${ }^{4}$ Instituto de Desenvolvimento Rural do Paraná (IDR), Londrina-PR, Brasil; ffavorettofurlan@gmail.com; ${ }^{5}$ Integrada Cooperativa Agroindustrial, Cambé-PR, Brasil; robsonagro2014@gmail.com

\begin{abstract}
"Dedo-de-moça" (Capsicum baccatum var. pendulum) is one of the main chili peppers grown worldwide. However, studies on genetics and breeding of this species are rare, when compared to other Capsicum species, manly in relation to physiological seed quality traits. In this sense, this study aimed to evaluate the combining ability of "dedo-de-moça" chili pepper in relation to physiological seed quality traits, determine the gene effects involved in the expression of these traits, and identify promising hybrid combinations. Crosses among five parents (Hortivale, Horticeres, Brs Mari, UEL 110 and UEL 111) in a full diallel mating design, resulted in $20 \mathrm{~F}_{1}$ hybrids. Griffing's diallel model was used to estimate general and specific combining ability (GCA and SCA, respectively) as well as the reciprocal effect (RE). Wide genetic variability was observed for all evaluated traits. Significant effects of GCA, SCA and RE were also verified for all traits, showing that additive, non-additive and cytoplasmic effects are involved in the genetic control of physiological seed quality. Non-additive effects were predominant for all traits, being UEL $111(\widehat{\jmath}) \times$ Hortivale $(+)$ and Hortivale $(\widehat{\sigma})$ $\times$ UEL $110(+)$ considered promising hybrids for obtaining more vigorous seeds with higher germination and greater longevity.
\end{abstract}

Keywords: Capsicum baccatum, complete diallel, general and specific combining ability, reciprocal effect.

\section{RESUMO}

Análise dialélica de sementes de pimenta "dedo-de-moça" em relação ao potencial fisiológico

A pimenta "dedo-de-moça" (Capsicum baccatum var. pendulum) é uma das principais pimentas cultivadas mundialmente. Todavia, são escassos estudos genéticos e de melhoramento desta quando comparados a outras espécies de Capsicum, principalmente, sobre a qualidade fisiológica de sementes. Nesse sentido, objetivou-se avaliar a capacidade combinatória de pimentas "dedo-de-moça" em relação à qualidade fisiológica de sementes, determinar os efeitos gênicos envolvidos na expressão dessas características, bem como identificar combinações híbridas promissoras. Os cruzamentos entre cinco genitores (Hortivale, Horticeres, Brs Mari, UEL 110 e UEL 111) em esquema de dialelo completo resultaram na formação de 20 híbridos $\mathrm{F}_{1}$. O modelo de dialelo de Griffing foi utilizado para determinar a capacidade geral e específica de combinação (CGC e CEC, respectivamente) e o efeito recíproco (ER). Foi observada ampla variabilidade genética para todas as características analisadas. Efeitos significativos para CGC, CEC e ER foram verificados para todas as características, indicando que os efeitos aditivos, não aditivos e citoplasmáticos estão envolvidos no controle genético da qualidade fisiológica de sementes. Os efeitos gênicos não aditivos foram predominantes em relação aos aditivos. As combinações híbridas UEL $111(\precsim) \times$ Hortivale () e Hortivale $(ð) \times$ UEL 110 (ㅇ) foram consideradas promissoras para obtenção de sementes mais vigorosas, com maior germinação e longevidade.

Palavras-chave: Capsicum baccatum, dialelo completo, capacidade geral e específica de combinação, efeito recíproco.

\section{Received on August 27, 2019; accepted on June 18, 2020}

$\mathrm{D}$ edo-de-moça" pepper (Capsicum baccatum var. pendulum) belongs to Solanaceae family. "Dedo-de-moça" is one of the main species grown in Brazil, mostly by family farmers (Rufino \& Penteado, 2016). Despite its economic importance, genetic studies and breeding programs of this species are rare when compared to other Capsicum species, mainly studies on physiological seed quality.

This is a perennial, shrubby plant, exploited as an annual plant, showing a wide genetic variability. This species is often found in South America. The fruits are used as natural flavoring, food dyes, cosmetics, jelly, pickled, sauces and dehydrated, in pharmacy industry, medicine and ornamental use, besides its potential for in natura consumption.
Pepper is consumed mainly in South and Southeast regions of Brazil (Mo et al., 2015; Gomes et al., 2017; Santana et al., 2017).

The vegetable seed market has been growing over the past few years. However, a low supply of quality seeds can be a limiting factor for large-scale production of "dedo-demoça” pepper (Carvalho et al., 2009), 
and this supply is related to several factors, such as deficient production techniques, physiological maturation stage, low yield, seed extraction difficulties, harvesting and lack of superior genotypes in the production of seeds with high physiological potential (Nascimento et al., 2006).

Using seeds with higher physiological vigor is essential to reduce exposure time of seeds and seedlings in order to avoid weather, biological adversities, and deteriorative processes or contamination by pathogens. Also, seeds with higher physiological vigor may obtain higher yields and fruits with higher commercial and nutritional quality (Marcos-Filho, 2015).

Brazil is an important center of genetic diversity of the genus Capsicum having a wide range of peppers and green peppers (Costa et al., 2015). This diversity has been exploited in vegetable breeding programs. This variability can be used to identify genotypes with high physiological potential of seeds in order to develop a new cultivar, or in future hybridizations. However, little is known about the genetic effects on vigor determination and seed germination of Capsicum baccatum.

Diallel crosses are efficient as methodology to help out in generating relevant information for breeding, such as for selecting parents for hybridization, identifying more efficient selection methods and knowledge about genetic bases which control the traits (Nascimento et al., 2010).

Griffing (1956) proposed one of the main methodologies for dialed analysis, which estimates the effects of general and specific combining ability. Thus, this study aimed to evaluate combining ability of "dedo-de-moça" peppers in relation to traits of seed physiological quality, determine gene effects involved in the expression of these traits, as well as identify promising hybrid combinations.

\section{MATERIAL AND METHODS}

Five parents of Capsicum baccatum var. pendulum were used, being three cultivars (Horticeres, Hortivale and
BRS Mari) and two accessions of the Capsicum spp. Germplasm Bank of Universidade Estadual de Londrina (UEL) (UEL 110 and UEL 111).

Hybridization was carried out in a greenhouse in a complete diallel scheme with inclusion of reciprocals, obtaining a total of 20 hybrid combinations. Eight plants per parent were used, and crossings were done between January and April, 2016. The flower buds of female parents were emasculated prior to anthesis and after crossed pollination the flowers were protected in paper bags to avoid contamination with undesirable pollen (Costa et al., 2009). Fruits obtained from hybridization were identified, harvested at 75 days after anthesis and the seeds were extracted, washed and dried.

In order to obtain seedlings, the genotypes were sown in expanded polystyrene trays. After the first two pairs of definitive leaf appeared, the seedlings were transplanted into the experimental field of UEL $\left(23^{\circ} 19^{\prime} 41^{\prime}\right.$ 'S, $51^{\circ} 12^{\prime} 18^{\prime \prime} \mathrm{W}$, altitude $550 \mathrm{~m}$ ). The soil of the experimental area is classified as Red Eutroferric Latossol and climate, according to Köppen, is Cfa. Randomized complete block designs, with three replicates and six plants per plot were used. Plant spacing was $1.0 \times 0.8 \mathrm{~m}$ between rows and plants. Diallel analysis was performed using Griffing's method 1 (1956), in which parents and set of the $F_{1}$ hybrids and reciprocals were included.

Fertilization was based on soil analysis and other cultural practices (hoeing, tutoring and sprinkler irrigation) were performed according to usual management recommendations for the crop (Filgueira, 2013). Fruits were harvested between 70 and 80 days after anthesis (DAA).

Approximately 60 fruits per plot were randomly obtained. Seeds were submitted to the following evaluations:

Dry mass of 50 seeds (MSS) - four replicates of 50 seeds, freshly extracted from the fruit, were put in a greenhouse at $105 \pm 3^{\circ} \mathrm{C}$, for 24 hours, and the results were expressed in $\mathrm{mg} \mathrm{seed}^{-1}$.

Germination (GER) - seeds were sown in transparent polyethylene boxes
$(11 \times 11 \times 3 \mathrm{~cm})$, on two germination paper sheets, moistened with a solution of $\mathrm{KNO}_{3}$ at $0.2 \%$ at a ratio of 2.5 times the dry paper weight. The boxes were kept in a germinator under alternating temperature of $20-30^{\circ} \mathrm{C}$ and eight hours of light. Evaluations were carried out on the eighth and fourteenth day after sowing, and the results were expressed in percentage of normal seedlings (Brasil, 2009).

First germination count (PC) percentage of normal seedlings on the eighth day of germination test.

Electrical conductivity (CE) - four replicates of 50 seeds, with known masses, were used. The seeds were immersed in $25 \mathrm{~mL}$ distilled water and kept in a BOD incubator at $25^{\circ} \mathrm{C}$, for 48 hours (Vidigal et al., 2008). After this period, the electrical conductivity of each solution was determined with the aid of a conductivity meter, and the results were expressed in $\mu \mathrm{S} \mathrm{cm}^{-1} \mathrm{~g}^{-1}$ of seeds.

Germination speed index (IVG) seeds which emerged until the fourteenth day after sowing were counted daily (Maguire, 1962).

Accelerated aging test (EA) - 1.0 $\mathrm{g}$ of seeds was uniformly distributed on a screen tray attached to gerbox-type plastic boxes, with $40 \mathrm{~mL}$ distilled water at the bottom. The seeds were kept in an incubator at $42^{\circ} \mathrm{C}$, for 96 hours (Bhering et al., 2006). Afterwards, 4 replicates of 50 seeds of each treatment of the five varieties were put to germinate, following the method described for germination test. A single evaluation was performed on the fourteenth day and the percentage of normal seedlings was computed.

Data were submitted to variance analysis $(p<0.05)$ and, then, estimates of general and specific combining ability and reciprocal effect were obtained using Griffing diallel analysis model (1956) to estimate the general (GCA) and specific (SCA) combining ability and reciprocal effect. The geneticstatistical analyses were carried out using Genes software (Cruz, 2016).

\section{RESULTS AND DISCUSSION}

Through variance analyses, the 
authors verified a significant effect $(p<0.05)$ for genotypes, for all evaluated traits (Table 1). The accurate selection showed values superior to 0.90 for all traits, resulting in greater credibility in the selection of superior genotypes and higher-experimental quality (Table 1).

Unfolding the sum of genotype squares to sum of squares of the general (GCA) and specific (SCA) combining ability, as well as reciprocal effect, was significant for all traits, indicating that additive, non-additive and cytoplasmatic genetic effects participated in the gene control of seed physiological potential of "dedo-de-moça" pepper.

This is an important fact, since this is an autogamous species, in which superior values for these traits can be fixed over successive generations of self-fertilization, obtaining inbred lines superior than those already existing (Rodrigues et al., 2012). In addition, the GCA $(\phi \mathrm{g}) / \mathrm{SCA}(\phi \mathrm{s})$ ratio showed values below one, which indicates predominance of non-additive effects over additive effects (Table 1) (Nascimento et al., 2010).

Barroso et al. (2017) evaluated seed germination percentage and growth and development of morphological traits of $\mathrm{F}_{1 \mathrm{~s}}$ hybrid seedlings by crossing different pepper parents of the genus Capsicum, and reported that these traits were controlled by additive and non-additive effects, and, as in this study, with a predominance of dominance effects related to SCA. Aiswarya et al. (2020) verified the $\mathrm{GCA}(\phi \mathrm{g}) / \mathrm{SCA}(\phi \mathrm{s})$ ratio less than one for morpho-agronomic traits, such as plant height, number of primary branches per plant, days to flowering, fruit length and circumference, yield of fruits and seeds, and for percentages of caspsaicin, oleoresin and ascorbic acid in a study of complete diallel with different Capsicum annuum genotypes.

The highest estimates of GCA effects for the traits first germination count (PC), germination speed index (IVG) seed dry mass (MSS) were obtained using the parent UEL $110(11.66 \% ; 0.70$; and $0.008 \mathrm{mg}$, respectively), followed by the parent UEL $111(8.14 \% ; 0.58$; and $0.008 \mathrm{mg}$, respectively) (Table 2). Parent UEL 111 also showed higher estimates of GCA for germination percentage (GER) and accelerated aging (EA), $9.80 \%$ and $13.19 \%$, respectively.

According to Marcos Filho (2015), seed physiological quality is determined as the ability of seeds to perform their vital functions, such as germination, vigor and longevity, which directly affect the crop in field conditions. Thus, parents UEL 110 and UEL 111 show high potential for breeding programs aiming to improve attributes related to seed physiological potential of "dedode-moça" pepper.

Moreover, using high-quality pepper seeds at the beginning of planting results in strong, vigorous, well-developed seedlings, being able to establish under different edaphoclimatic conditions, with greater emergence speed and plant growth. As a consequence, the plant in the field will show less problems with weed incidence, need for herbicides, reseeding and others, ensuring greater performance and productivity (Nakada et al., 2011).

However, preponderance of nonadditive effects in this study indicates the possibility of hybrid vigor exploration, as mentioned by Barroso et al. (2017) and Aiswarya et al. (2020), since $\mathrm{F}_{1}$ hybrids have been increasingly used commercially (Jeeatid et al., 2018).

Using estimates of SCA effects, we verified negative effects for hybrids UEL $111 \times$ UEL 110 and Horticeres $\times$ Hortivale for EA, PC, GER, IVG and MSS, suggesting that these hybridizations are unfavorable for these traits (Table 2). On the other

Table 1. Estimates of the mean squares of genotypes, general combining ability (GCA), specific combining ability (SCA), reciprocal effect and the quadratic components of CGA and SCA of electrical conductivity (CE), accelerated aging (EA), first count (PC), germination (GER), germination speed index (IVG) and seed dry mass (MSS) evaluated in Capsicum baccatum var. pendulum. Londrina, UEL, 2019.

\begin{tabular}{|c|c|c|c|c|c|c|c|}
\hline \multirow{2}{*}{ FV } & \multirow{2}{*}{ GL } & \multicolumn{6}{|c|}{ Mean square ${ }^{1 /}$} \\
\hline & & $\mathbf{C E}^{2 /}$ & $\mathbf{E A}$ & PC & GER & IVG & MSS \\
\hline Genotypes & $(24)$ & $568.77 * *$ & $303.63 * *$ & $207.14 * *$ & $188.60 * *$ & $10.24 * *$ & $51.39 * *$ \\
\hline GCA & 4 & $519.89 * *$ & $474.55^{* *}$ & $522.44 * *$ & $432.30 * *$ & $23.74 * *$ & $48.47 * *$ \\
\hline SCA & 10 & $257.04 * *$ & $297.28 * *$ & $132.93 * *$ & $131.48 * *$ & $7.37 * *$ & $30.69 * *$ \\
\hline Reciprocal & 10 & $900.04 * *$ & $241.60 * *$ & $155.22 * *$ & $148.24 * *$ & $7.70 * *$ & $73.25^{* *}$ \\
\hline Residual & 75 & 27.07 & 19.12 & 15.08 & 14.45 & 0.84 & 51.39 \\
\hline Average & & 385.18 & 52.66 & 57.44 & 72.90 & 44.4 & 0.0132 \\
\hline Accuracy & & 0.95 & 0.96 & 0.94 & 0.92 & 0.93 & 0.90 \\
\hline \multicolumn{8}{|c|}{ Quadratic components } \\
\hline$\widehat{\Phi}$ ge & & 123.05 & 113.86 & 126.84 & 104.46 & 0.572 & 0.001 \\
\hline$\widehat{\Phi}_{\mathrm{se}}$ & & 574.91 & 695.35 & 294.63 & 292.47 & 1.632 & 0.005 \\
\hline$\widehat{\Phi}_{\mathrm{ge}} / \widehat{\Phi}_{\mathrm{se}}$ & & 0.21 & 0.16 & 0.43 & 0.36 & 0.35 & 0.200 \\
\hline
\end{tabular}

$1 / * *=$ significant at $1 \%$ probability by $\mathrm{F}$ test. ${ }^{2 / \mathrm{CE}}=\mu \mathrm{S} \mathrm{cm}^{-1} \mathrm{~g}^{-1}$ of seeds; $\mathrm{EA}=\% ; \mathrm{PC}=\% ; \mathrm{GER}=\% ; \mathrm{MMS}=\mathrm{mg}$. 
hand, hybrids UEL $111 \times$ Hortivale and Hortivale $\times$ UEL 110 , showing greater effects of SCA for PC, GER and IVG, respectively, provided seed hybrids with greater vigor and germination, considering these traits favorable and essential to produce high physiological potential seeds.

According to Hallauer et al. (2010) SCA effects manifest in relation to dominance effects and differences in allele frequencies of parents for the loci involved in the control of a given character.

Hybrids Hortivale $\times$ BRS Mari, UEL $111 \times$ Horticeres, BRS Mari $\times$ UEL 110, Horticeres $\times$ BRS Mari, UEL 111 $\times$ BRS Mari and UEL $111 \times$ Hortivale, respectively, showed higher values of SCA for EA, considering that this trait is related to storage capacity, resulting in a lower deterioration speed (Table 2)
(Marcos-Filho, 2015)

The effect of reciprocal crosses was significant for all evaluated traits (Table 1), which demonstrated the importance of cyto-nuclear interactions in these traits. The genomes of cellular organelles containing DNA (mitochondria and chloroplasts) play an important role in genotypic variation; this genoma has been underestimated, though (Roux et al., 2016).

Table 2. Estimates of general combining ability (ĝij), specific combining ability (ŝij) and reciprocal effects (rij) for electrical conductivity (CE), accelerated aging (EA), first count (PC), germination (GER), germination speed index (IVG) and seed dry mass (MSS) evaluated in Capsicum baccatum var. pendulum. Londrina, UEL, 2019.

\begin{tabular}{|c|c|c|c|c|c|c|}
\hline \multirow{2}{*}{ Parent } & \multicolumn{6}{|c|}{ General combining ability } \\
\hline & $\mathbf{C E}^{2 /}$ & EA & PC & GER & IVG & MSS \\
\hline UEL 111 & -6.71 & 13.19 & 8.14 & 9.80 & 0.58 & 0.008 \\
\hline Horticeres & 20.64 & 7.22 & 4.36 & -2.40 & 0.24 & -0.010 \\
\hline Hortivale & -35.05 & -15.09 & -14.27 & -16.30 & -1.17 & -0.009 \\
\hline BRS Mari & -29.91 & -0.81 & -9.89 & 0.90 & -0.36 & 0.003 \\
\hline UEL 110 & 51.03 & -4.51 & 11.66 & 8.00 & 0.70 & 0.008 \\
\hline $\mathrm{DP}\left(\mathrm{g}_{\mathrm{i}}-\mathrm{g}_{\mathrm{j}}\right)$ & 11.63 & 3.09 & 2.75 & 2.68 & 0.21 & 0.001 \\
\hline Hybrids & \multicolumn{6}{|c|}{ Specific combining ability } \\
\hline UEL $111 \times$ Horticeres & 25.59 & 12.19 & 0.32 & 5.45 & -0.29 & 0.082 \\
\hline UEL $111 \times$ Hortivale & 44.14 & 0.61 & 17.19 & 19.85 & 1.713 & 0.076 \\
\hline UEL $111 \times$ BRS Mari & -46.68 & 2.96 & 5.19 & -3.10 & -0.32 & -0.055 \\
\hline UEL $111 \times$ UEL 110 & 24.08 & -20.72 & -7.49 & -12.70 & -0.69 & -0.030 \\
\hline Horticeres $\times$ Hortivale & -124.64 & -6.54 & -16.54 & -19.70 & -1.14 & -0.379 \\
\hline Horticeres $\times$ BRS Mari & 46.92 & 5.69 & 21.09 & 8.60 & 1.59 & -0.073 \\
\hline Horticeres $\times$ UEL 110 & 74.43 & -13.24 & 0.79 & 3.25 & 0.08 & 0.139 \\
\hline Hortivale $\times$ BRS Mari & 48.87 & 30.61 & -5.66 & -5.00 & -0.68 & 0.154 \\
\hline Hortivale $\times$ UEL 110 & -11.20 & -4.19 & 10.42 & 19.15 & 0.89 & 0.036 \\
\hline BRS Mari $\times$ UEL 110 & -9.46 & 9.79 & 2.04 & -2.80 & -0.27 & -0.049 \\
\hline $\operatorname{DP}\left(s_{\mathrm{ij}}-s_{\mathrm{kl}}\right)$ & 20.15 & 5.36 & 4.76 & 4.65 & 0.36 & 0.031 \\
\hline Hybrids $^{1} / \delta^{\Uparrow} \uparrow$ & \multicolumn{6}{|c|}{ Reciprocal effect } \\
\hline UEL $111 \times$ Horticeres & $-48.50 *$ & $-6.25^{\mathrm{ns}}$ & $0.25^{\mathrm{ns}}$ & $-0.75^{\mathrm{ns}}$ & $-0.26^{\mathrm{ns}}$ & $0.088 *$ \\
\hline UEL $111 \times$ Hortivale & $25.30^{\mathrm{ns}}$ & $18.12 *$ & $-5.00^{\mathrm{ns}}$ & $-2.75^{\mathrm{ns}}$ & $-0.29^{\mathrm{ns}}$ & $-0.079 *$ \\
\hline UEL $111 \times$ BRS Mari & $-49.11 *$ & $14.00 *$ & $-12.38 *$ & $-7.00^{\mathrm{ns}}$ & $-0.92 *$ & $0.115^{*}$ \\
\hline UEL $111 \times$ UEL 110 & $-16.78^{\mathrm{ns}}$ & $-19.62 *$ & $-6.25^{\mathrm{ns}}$ & $-9.50 *$ & $-0.60^{\mathrm{ns}}$ & $0.067^{*}$ \\
\hline Horticeres $\times$ Hortivale & $263.75^{*}$ & $38.25^{*}$ & $31.00^{\mathrm{ns}}$ & $34.50 *$ & $2.39^{\mathrm{ns}}$ & $0.749 *$ \\
\hline Horticeres $\times$ BRS Mari & $-51.56^{*}$ & $0.25^{\mathrm{ns}}$ & $-7.50^{\mathrm{ns}}$ & $-6.50^{\mathrm{ns}}$ & $-0.69 *$ & $-0.035^{\mathrm{ns}}$ \\
\hline Horticeres $\times$ UEL 110 & $-93.17 *$ & $-14.37^{*}$ & $1.75^{\mathrm{ns}}$ & $1.75^{\mathrm{ns}}$ & $0.43^{\mathrm{ns}}$ & $-0.025^{\mathrm{ns}}$ \\
\hline Hortivale $\times$ BRS Mari & $72.20^{*}$ & $14.87 *$ & $-17.62 *$ & $-16.00 *$ & $-0.62^{\mathrm{ns}}$ & $0.052^{\mathrm{ns}}$ \\
\hline Hortivale $\times$ UEL 110 & $-31.02 \mathrm{~ns}$ & $7.875^{\mathrm{ns}}$ & $13.75^{*}$ & $12.25^{*}$ & $0.79 *$ & $0.005^{\mathrm{ns}}$ \\
\hline BRS Mari $\times$ UEL 110 & $140.50^{*}$ & $10.87^{*}$ & $14.25^{*}$ & $8.00^{\mathrm{ns}}$ & $0.96^{*}$ & $-0.079^{*}$ \\
\hline $\operatorname{DP}\left(r_{i i}-r_{k 1}\right)$ & 26.01 & 6.91 & 6.14 & -0.75 & -0.26 & 0.040 \\
\hline
\end{tabular}

${ }^{1}$ ns and $*=$ not significant and significant at $5 \%$ probability by t test, respectively. ${ }^{2} \mathrm{CE}=\mu \mathrm{S} \mathrm{cm} \mathrm{cm}^{-1} \mathrm{~g}^{-1}$ of seeds; $\mathrm{EA}=\%$; $\mathrm{PC}=\%$; GER $=\%$; $\mathrm{MMS}=\mathrm{mg}$. 
Barroso et al. (2017) reported the presence of reciprocal effect in diallel with peppers of the genus Capsicum. According to these authors, the underlying genetic basis of the reciprocal differences for the in vitro response of germination and early development of pepper seedlings can be related to cytoplasmic factors, such as mtDNA, physiological characteristics of maternal plants or segregation of nuclear factors from the maternal parent.

Considering the two more promising hybrid combinations (UEL $111 \times$ Hortivale and Hortivale $\times$ UEL 110), based on SCA, hybrid UEL $111 \times$ Hortivale presented significant reciprocal effect for EA and MSS, showing positive and advantageous effects for EA, when the genotype Hortivale is fixed as a female parent. The hybrid Hortivale $\times$ UEL 110 showed gains in vigor (positive effects in PC) and in germination, using its reciprocal with genotype UEL 110 as female parent (Table 2).

Despite being significant, GCA, SCA and reciprocal effects on electrical conductivity (EC) (Tables 1 and 2) are little related to other important traits, such as accelerated aging, first germination count, germination speed and percentage of normal seedlings. Considering the above, this analysis showed to be little informative for selecting parents to obtain seeds with high physiological potential.

We concluded that the physiological potential of Capsicum baccatum var. pendulum seeds is governed by additive, non-additive and cytoplasmic genetic effects. The preponderance of non-additive effects indicates that the exploitation of hybrid vigor can be considered a relevant strategy to obtain superior genotypes. The hybrids UEL $111(\delta) \times$ Hortivale $($ ( $)$ and Hortivale $\left({ }^{\lambda}\right) \times$ UEL 110 (ㅇ) were considered promising for obtaining more vigorous seeds, with greater germination and longevity.

\section{ACKNOWLEDGMENTS}

Gisely Paula Gomes, Lúcia SA Takahashi and Leandro SA Gonçalves are grateful to Fundação Araucária and Coordenação de Aperfeiçoamento de Pessoal de Nivel Superior (CAPES) (Coordination for Improvement of Higher Education Personnel) for funding this project.

\section{REFERENCES}

A I S W A R Y A, C S ; V I J E T H , S ; SREELATHAKUMARY, I; PRASHANT K. 2020. Diallel analysis of chilli pepper (Capsicum annuum L.) genotypes for morphological and fruit biochemical traits. Plants 9: 1-15.

BARROSO, PA; RÊGO, MM; RÊGO ER; FERREIRAS, KTC. 2017. Genetic effects of in vitro germination and plantlet development in chilli pepper. Genetics and Molecular Research 16: 2-10.

BHERING, MC; DIAS, DCFS; VIDIGAL, DS; NAVEIRA, DSP. 2006. Teste de envelhecimento acelerado em sementes de pimenta. Revista Brasileira de Sementes 28: 64-71.

BRASIL. Ministério da Agricultura, Pecuária e Abastecimento. 2009. Regras para análise de sementes. SDA. Brasília: Mapa/ACS. 399p.

CARVALHO, SIC; RIBEIRO, CSC; HENZ, GP; REIFSCHNEIDER, FJB. 2009. 'BRS Mari': Nova cultivar de pimenta dedo de moça para processamento. Horticultura Brasileira 27: 571-573.

COSTA, LV; LOPES, R; LOPES, MTG; FIGUEIREDO, AFF; BARROS, WS; ALVES, SRM. 2009. Cross compatibility of domesticated hot pepper and cultivated sweet pepper. Crop Breeding and Applied Biotechnology 9: 37-44.

COSTA, LV; BENTES, JLS; LOPES, MTG; ALVES, SRM; VIANA JÚNIOR, JM. 2015. Caracterização de acessos de pimentas do Amazonas. Horticultura Brasileira 33: 290298.

CRUZ, CD. 2016. Programa Genes - Ampliado e integrado aos aplicativos R, Matlab e Selegen. Acta Scientiarum Agronomy 38: 547-552.

FILGUEIRA, FAR. 2013. Novo manual de olericultura: agrotecnologia moderna na produção e comercialização de hortaliças. 3 . ed. rev. ampl. Viçosa: UFV. 421p.

GOMES, GP; DAMASCENO JUNIOR, CV; DA COSTA, DS; QUEIROZ., RA; BABA, VY; TAKAHASHI, LSA; GONÇALVES, LSA.
2017. Harvest season and seed physiological potential of 'dedo-de-moça BRS Mari' hot peppers. Semina: Ciências Agrárias 38: 3897-3906.

GRIFFING, B. 1956. Concept of general and specific combining ability in relation to diallel crossing systems. Australian Journal of Biological Sciences 9: 463-493.

HALLAUER, AR; MIRANDA FILHO, JB; MJ CARENA. 2010. HETEROSIS. IN: HALLAUER, AR; MIRANDA FILHO, JBMJ. CARENA (eds). Quantitative genetics in maize breeding. New York: Springer. p.477-459

JEE AT I D, N; S U R I H A R N A, B ; TECHAWONGSTIENA, S; CHANTHAIB, S; BOSLANDC, PW; TECHAWONGSTIENA, S. 2018. Evaluation of the effect of genotypeby-environment interaction on capsaicinoid production in hot pepper hybrids (Capsicum chinense Jacq.) under controlled environment. Scientia Horticulturae 235: 334-339.

MAGUIRE, JD. 1962. Steps of germinationaid selection and evaluation for seedling emergence and vigor. Crop Science 2: 176-177.

MARCOS FILHO, J. 2015. Fisiologia de sementes de plantas cultivadas. Londrina: ABRATES. 659p.

MO, HS; JANG, KS; HWANG, JE; JEON, SG; KIM, BS. 2015. Horticultural and chemical quality characterization of accessions selected from four species of Capsicum. Horticulture, Environment, and Biotechnology, 56: 54-66.

NAKADA, PG; OLIVEIRA, JA; MELO, LC; GOMES, LAA; PINHO, EVR. 2011. Desempenho fisiológico e bioquímico de sementes de pepino nos diferentes estádios de maturação. Revista Brasileira de Sementes 33: 113-122.

NASCIMENTO, WM; FREITAS, RA. 2006. Produção de sementes de pimentas. Cultivo de pimentas (Capsicum spp.) no Brasil. Brasília: Embrapa Hortaliças. p.30-39.

NASCIMENTO, IR; MALUF, WR; GONÇALVES, LD; FARIA, MV; RESENDE, JTV; NOGUEIRA, DW. 2010. Capacidade combinatória de linhagens de pimentão a partir de análise dialélica multivariada. Acta Scientiarum. Agronomy, 32: 235-240.

RODRIGUES, R; GONÇALVES, LSA; BENTO, CS; SUDRÉ, CP; ROBAINA, RR; AMARAL JÚNIOR, AT. 2012. Combining ability and heterosis for agronomic traits in chili pepper. Horticultura Brasileira 30: 226-233.

ROUX, F; MARY-HUARD, T; BARILLOT, E; WENES, E; BOTRAN, L; DURAND, S; VILLOUTREIX, R; MARTIN-MAGNIETTE, ML; CAMILLERI, C; BUDAR, F. 2016. Cytonuclear interactions affect adaptive traits of the annual plant Arabidopsis thaliana in the field. Proceedings of the National Academy of Sciences of the United States of America 113: 3687-3692. 